\title{
Ecology is key to effective aid, UN told
}

Support is growing for the idea of linking aid with environmental protection. A new report proposes that enabling local communities to manage natural resources is the key to tackling poverty. In response, development experts are calling for a more scientific approach to deciding how aid money should be spent.

The Wealth of the Poor, backed by the United Nations (UN) and the World Bank, says that governments have ignored the 750 million rural people who make up three-quarters of the poor, and that development in areas such as China and India has largely bypassed rural areas. Marine and agricultural resources around the world are being depleted as smallscale farmers struggle to feed their families.

${ }^{\alpha}$ Development strategies represent the priorities of capital cities and finance ministers," says Jonathan Lash, president of the World Resources Institute in Washington DC, the environmental think-tank that wrote the report.

It follows a global environmental survey that concluded, in March, that ecosystems around the world are in decline and will continue to be so unless their value is factored into financial thinking (see Nature 434, 547; 2005).

One solution, suggests the report, is for development agencies to focus on wealth created when people work together to manage local ecosystems. During the past decade, for example, communities in Fiji have reversed a dedine in marine catches by confining fishing to restricted areas. In northern Tanzania, land reforms helped villagers band together to succeed where overseas agencies had failed, reforesting around 3,500 square kilometres of badly degraded land that now provides fuel and food.

But the report includes few such successes. "If you tried to find 50 more you couldn't," says Lash. Organizations such as the World Bank do not consider the 'ecosystem services' that underpin the successful case studies, he says.

"That's a correct and important point," says Jeffrey Sachs, director of the Earth Institute at Columbia University in New York. If ecosystem services are not taken into account, he says, aid agencies go on supporting such schemes as fisheries that raise incomes in the short term but reduce community resources as fish stocks shrink.

Sachs adds that development agencies fail to involve researchers in schemes that focus on ecosystem services. ${ }^{\alpha}$ There is lots of good science available, but very little is tapped for public policy," he says. "We have two cultures. Most people who have trained in economics are not trained in science."

Scientific input, say the few researchers who have taken part, can help people see if changes are working and test out future options.

In KwaZulu-Natal, South Africa, for example, scientists helped local women design experiments to assess the ecological impact of different clam-harvesting strategies.

"The point is for scientists to help communities gather the information they need to manage their marine resources better, rather than telling them what to do," says Bill Aalbersberg, an applied ecologist at the University of the South Pacific in Fiji, who helped communities monitor the impact of no-catch zones.

Some development agencies say they are taking the message on board. The UK Department for International Development, for example, last year appointed a chief science adviser and announced plans to increase its research budget by more than $\mathrm{f50}$ million (US $\$ 90$ million) to $£ 135$ million in 2007. It says it is working with environmental organizations such as the WWF to ensure that the work it supports involves local stewardship of natural resources.

Lash hopes that the report will influence the UN's Millennium Development Goals, a set of targets agreed in 2000 . The goals, which have been criticized for treating poverty and the environment as separate issues, are to be discussed in New York next week. But Lash fears his plans may have been derailed by US ambassador John Bolton, who has requested revisions that could water the goals down. Jim Giles 